\title{
Squamous Cell Carcinoma Developing Over Lupus Vulgaris
}

\author{
S Aktan, I Gokalan Kara, N Demirkan, S Berna
}

\section{Citation}

S Aktan, I Gokalan Kara, N Demirkan, S Berna. Squamous Cell Carcinoma Developing Over Lupus Vulgaris. The Internet Journal of Dermatology. 2000 Volume 1 Number 1.

\section{DOI: $10.5580 / 113 a$}

\section{Abstract}

A sixty-year old woman with epidertnoid carcinoma developing over lupus vulgaris is presented.

Lupus vulgaris has been present for 20 years on malar regions and nose on which epidermoid carcinoma was diagnosed. This case has been successfully treated with wide range of tumor excision and antituberculous chemotherapy.

\section{INTRODUCTION}

Lupus vulgaris is a chronic, progressive form of tuberculosis of the skin occurring in individuals with a high degree of tuberculin sensitivity. The most serious complication of long-standing lupus vulgaris is the development of squamous cell carcinomas of the $\operatorname{skin}_{1}$. The incidence of cutaneous tuberculosis has been progressively decreasing in industrially developed countries during this century and this change has been attributed to improved living standards, hygiene and antituberculoid therapy ${ }_{2,3}$. In this case report, a woman with squamous cell carcinoma developing over lupus vulgaris is presented.

\section{CASE REPORT}

A sixty year-old woman complained of a rapidly growing lesion on her nose of one-year duration. She also defined erythematous lesions on the skin of her nose and on various parts of the skin of her face of which she has been aware for approximately twenty years (Figure 1). She pointed no medical care and no spontaneous regression but further progression for those lesions during that twenty year-period.

\section{Figure 1}

Figure 1: Clinical appearance of the lesions before therapy

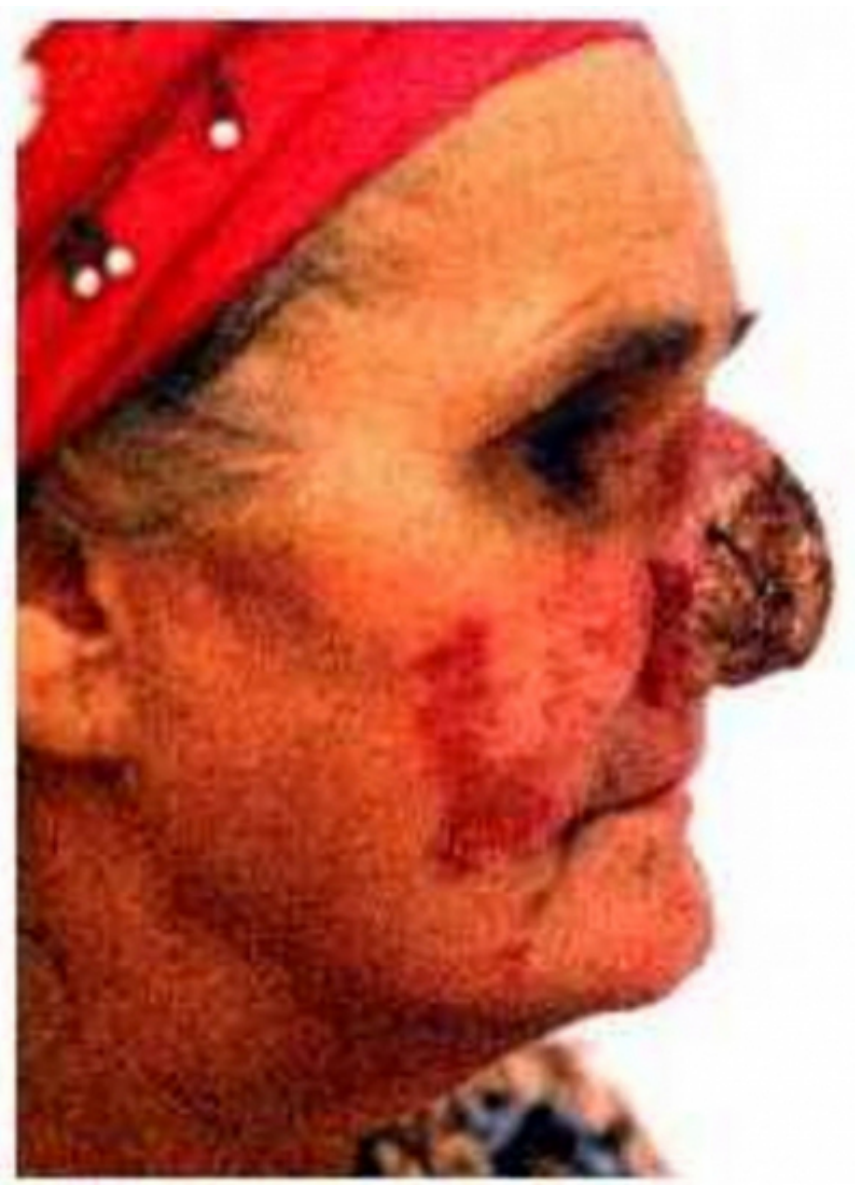

In the clinical examination; an ulcerated, crusted, hypertrophic, and elevated widespread lesion covering almost all of the nose was seen. In addition, multiple flat 
plaques brownish red in color with a polycyclic configuration and psoriasiform scaling, were also encountered on the skin of cheeks and filtrum. Upon diascopy the plaques showed apple-jelly colour. Physical examination revealed a $1 \times 1 \mathrm{~cm}$ lymph node enlargement in the right buccal region and no systemic disease. Laboratory findings including chest film were normal except for a strongly positive PPD skin test, Special staining of the exudates and the biopsy specimen with Ziehl-Neelson were negative. Cultures of the skin and urine were negative for mycobacteria. Biopsy specimen revealed a well differentiated squamous cell carcinoma extending into the dermis. Multiple granuloma formations with Langhans giant cells and epithelioid cells were encountered in the dermis adjacent to the regions invaded by the tumoral masses, Eosinophilic caseation necrosis were also found in the central part of some granuloma formations (Figure 2), As a surgical therapy wide range of tumor excision including the nose totally, and right superficial parotidectomy including the enlarged lymph node was performed preceding the total nose reconstruction.

\section{Figure 2}

Figure 2: Multiple granuloma formations with Langhans type giant cells adjacent to the tumoral nests (HEx 100)

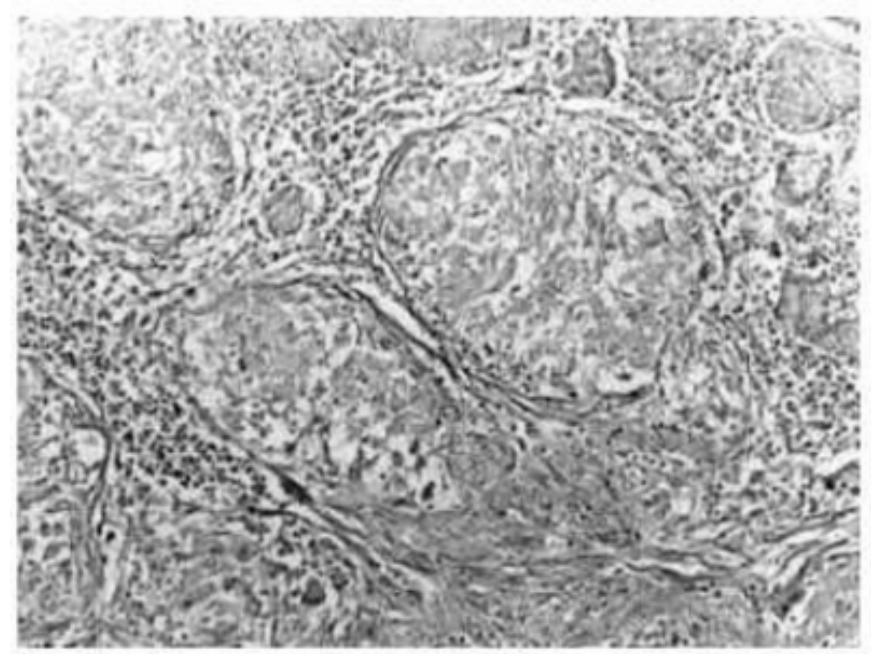

Histologic examination of the specimen revealed safe excision margins and no tumoral spread, and the cut sections of the infiltrative lesion on septum nasale disclosed multiple tubercules; the diagnosis was a well differentiated squamous cell carcinoma co-existing with lupus vulgaris. DNA of mycobacterium tuberculosis by PCR was negative. Antituberculosis chemotherapy, as isoniazid (300 mg/ day) and rifampicin (600 $\mathrm{mg}$ / day) was prescribed. The patient was called for periodic controls, and the lesions were observed to regress completely, and in the 9th month of atitituberculous chemotherapy.

\section{DISCUSSION}

$\mathrm{LV}$ is the commonest of all forms of tuberculosis of the skin. Although many diagnostic tools have been described for LV, none of them have been known to have adequate sensitivity. Culture in LV is frequently negative and only $6 \%$ of cutaneous cultures from patients with LV were reported to

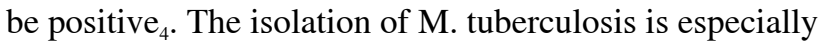
rare from lesions of LV present for many years, as most forms of cutaneous tuberculosis eg, LV are paucibacillary, and acid-fast bacteria are almost never seen microscopically $y_{6}$. Mantoux test is strongly positive in most cases of LV so a negative reaction provides strong evidence against tuberculosis2. There are several case reports indicating the usefiilness of PCR in the diagnosis of $\mathrm{LV}_{7,8}$. On the other hand, false positive and false negative results in detecting $\mathrm{M}$. tuberculosis DNA by PCR has also been reported6. In an analysis of 15 formalin-fixed, paraffinembedded skin specimens of clinically and histologically diagnosed cases of $\mathrm{LV}, 8$ specimens were found to contain M. tuberculosis complex $\mathrm{DNA}_{9}$. The sensitivity of PCR to detect mycobacterial DNA was reported to be $2-90 \%$ of the samples with 10 mycobacteria $_{10}$. Histopathologic examination also provides some clues for the diagnosis of LV. The most prominent features are the formation of multiple confluent granuloma with giant cells of Langhans type and epithelioid cells with sparse caseasion necrosis in the central part of some tubercules . $_{11}$

Our case presenting with clinical and histopathologic features of LV, and strongly positive Mantoux test, although other diagnostic tools failed to show mycobacteria or DNA of mycobacteria, led us to begin antituberculous therapy, considering the limited ability of those diagnostic tools that failed in our case. The dramatic improvement of the skin lesions following antituberculous therapy also supported our initial diagnosis. 1-Iistopathologic features of LV seen also in the part of the specimen including tumoral formation led us to think that this tumoral formation developed on the skin with LV.

Squamous cell carcinoma is the most important serious complication of long standing LV and although the incidence of this complication was estimated to be $10 \%$ early in this century1, only few cases were found to be reported recently.

This case is an example for LV and coexistent squamous cell carcinoma developed on the background of LV which was 
successfully treated with wide range of tumor excision and antituberculous chemotherapy for the coexisting skin lesions.

\section{References}

1. Tappeiner 0, Wolff K. Tuberculosis and other mycobacterial infections. In: Fitzpatrick

TB, Eisen AZ, Wolff K, Freedberg IM, Austen K (eds). Dermatology in General Medicine,

4th edn. New York: McGraw-Hill Inc., 1993; 2370-95.

2. Kakakhel KU, Fritsch P. Cutaneous tuberculosis. Int J Dermatol 1989; 28: 355-62.

3. Grange JM. Mycobacteria and the skin. Int J Dermatol 1982; $21: 497-503$.

4. Savin JA. Mycobacterial infections. In: Champion RH, Burton IL, Ebling FJG (eds).

Textbook of Dermatology, 5th edn. London: Blackwell Science, 1992; 1033-63.

5. Farina MC, Gegundez I, Pique F et al. Cutaneous tuberculosis: A clinical,

histopathologic, and bacteriologic study. J Am Acad Dermatol 1995; 33: 433-40.
6. Degitz K. Detection of Mycobacterial DNA in the skin, Arch Dermatol 1996; 132: 7 1-5.

7. Serfling U, Penneys MS, Leonardi CL. Identification of Mycobacterium tuberculosis

DNA in a case of lupus vulgaris. J Am Acad Dermatol 1993; 28: 318-22

8. Steidl M, Neubert U, Volkenandt $M$ et al. Lupus vulgaris confirmed by polymerase-chain

reaction. Br J Dermatol 1993; 129: 314-18.

9. Degitz K, Steidl M, Neubert U et al. Detection of mycobacterial DNA in paraffin-

embedded specimens of Lupus vulgaris by polymerase-chain reaction. Arch Dermatol Res

993; 285:168-70.

10. Noordhoek UT, KoIk Al-I, Bjune G et al. Sensitivity and specificity of PCR for

detection of Mycobacterium tuberculosis: a blind comparison study among seven

laboratories. J Clin Microbiol 1994; 32:277-84.

11. Mehregan AH, Hashimoto K, Mehregan DA, Mehregan

DR. Pinkus' Guide to

Dermatohistopathology, 6th edn. London: Appleton \& Lange, 1995; 301-2. 


\section{Author Information}

Sebnem Aktan, MD

Associate Professor, Dermatology, Dermatology, Pamukkale University Faculty of Medicine

\section{Inci Gokalan Kara, MD}

Assistant Professor, Plastic and Reconstructive Surgery, Plastic and Reconstructive Surgery, Pamukkale University Faculty of Medicine

\section{Nese Demirkan, MD}

Assistant Professor, Pathology, Pathology, Pamukkale University Faculty of Medicine

\section{Sanli Berna, MD}

Asistant Professor, Dermatology, Dermatology, Pamukkale University Faculty of Medicine 